226. 数値計算による P E T の回復係数

Numerical Calculation of The Recovery Coefficients in PET

千葉大学医学部附属病院放射線部

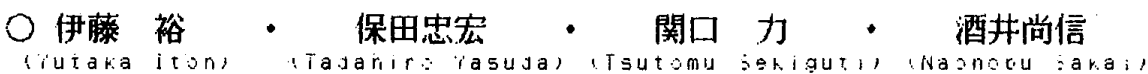

\title{
[目的拀よひ概要 $]$
}

現在市販されているPETO空間分解能は、5 mmから10mmでることから、

P E T で画像診断あるいは定量測定を行うために虫、R I が分布している形状から回復係数を求め てPETO出力画像（再構成画像）を補正してやらなけ机ならない。P E T O特性をPSFに限 っていえば、その出力である再構成画像は、入力とPSFのコンボリューションであると考えられ る。これまで回復係数は数式を解いて求めてきたが、樍分には限界があったため、槙分を数值計 算で行うことにした。この数值計算によって、対象とする形状を平板、円柱、球の回復係数を求め た。球と用柱の場合、数值計算と実湘值による回復係数讨ほほ近似した。さらに、長径 30 m!m、短 径 $10 \mathrm{~mm}$ の棈円の回転体（回転棈円体）の回復係数を計算した。数值計算によって、比較的自由な 形状の対象体の回復係数を計算できる。尚、この棈円体を例にして、座標の回転移動をすることに よって任意の方向からスライスした回復係数を計算できることも

確認儿地。

[方法]

数值積分の方法としては、ます、目的とする領域を細かく仯割 して、超直方体を考える。ある点 $\mathrm{P}$ の回復係数は、それぞれの 超值方体とPS F を重貫した值龙点Pにおいて加算することによ って求めることができる。さらに、座標の回転移動によって、対 象とする領域を任意の方向について計算できる。ここではX X 平面を P E T のスライス面、Z軸死体軸方向とした。（图.1） [結果およひまとめ]

図.2は、数値計算による平板、円柱、球のある 大きさにおけるそれぞれの中心についての回復係数 である。図.3は、長径30 mm、短径 $10 \mathrm{~mm}$ ○回転 棈円体の長軸を体軸方向（Z軸）に置き、Y Z 面を 0 度、30度、60度、90度に回転移動（X軸の 回転移動)したときのフロフィールの変化である。

図.4は、図.3と同じ回転棈円体について ZX面 を0度、30度、60度、90度に回転（Y軸の回 転移動）したときのブロフィールである。この回転 棈円体については、現在ファントムがないため、 湘定檤と比較していないが、形状が同しであってむ、 方向が違うことに

よって回復係数が

大きく異なること

を示している。

以上のように。

数値計算によっ

て比較的自由な

形状，方向に対

して。回復係数

計算し分析て

きることになる。

\section{図.3}

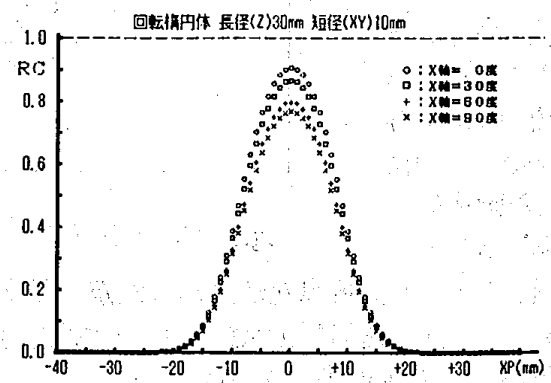

図.1

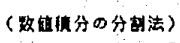

$\mathrm{Sv}=\mathrm{PSF} * \mathrm{DV}$

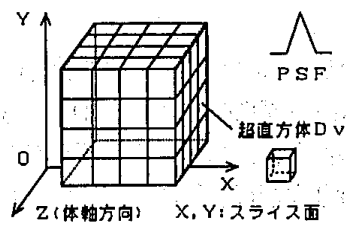

图.2

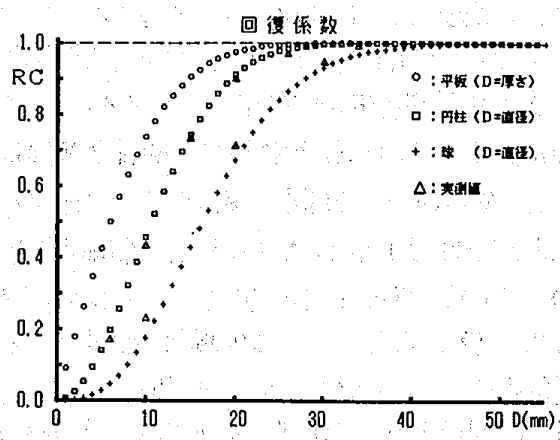

图.4

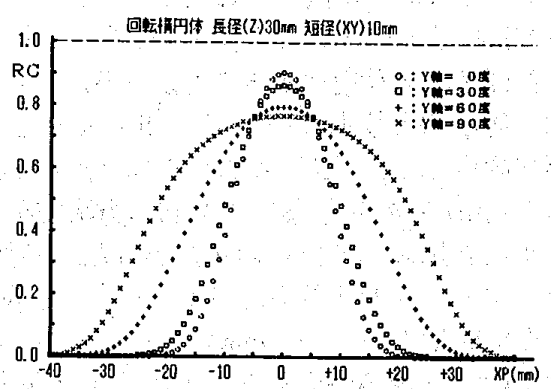

